\title{
Institutions on Public Open Space Governance
}

\author{
Gabriel H.T. Ling ${ }^{1}$, Chin Siong Ho ${ }^{1}$, \\ Hishamuddin Mohd Ali 2 \\ 1 Faculty of Built Environment, \\ 2 Faculty of Geoinformation and Real Estate, \\ Universiti Teknologi Malaysia UTM, 81310 Skudai, Johor, Malaysia \\ Ihtgabriel2@live.utm.my
}

\begin{abstract}
Meagre discussion on the institutional property-rights structure essence has rudimentarily determined the POS governance and its quality. Thus, two objectives are highlighted; (i) to examine Sabah's current practice (rights distribution) in urban-rural POS governance and (ii) explore the POS' social dilemmas that tied in with such institution. Reviews of interdisciplinary analytic perspectives, content analysis on documents and semi-structured interviews were performed. The practice with diverse property-rights structure is indicatively perceived as "property-rights tragedies", which ensue in sub-optimal POS and quality of life issues. Therefore, re-engineering of POS market via dynamic property-rights reassignment is postulated as the panacea for improved wellbeing.
\end{abstract}

Keywords: Diverse property-rights structure; POS governance; social dilemmas; quality of life

eISSN 2514-751X @ $\odot$ 2018. The Authors. Published for AMER ABRA cE-Bs by e-International Publishing House, Ltd., UK. This is an open-access article under the CC BY-NC-ND license (http://creativecommons.org/licenses/by$n c-n d / 4.0 /$ ). Peer-review under responsibility of AMER (Association of Malaysian Environment-Behaviour Researchers), ABRA (Association of Behavioural Researchers on Asians) and cE-Bs (Centre for EnvironmentBehaviour Studies), Faculty of Architecture, Planning \& Surveying, Universiti Teknologi MARA, Malaysia DOI: https://doi.org/10.21834/aje-bs.v3i10.314 


\subsection{Introduction}

Recurring issues concerning the governance regarding usage and conservation of idiosyncratic public open space (POS) have critically been debated on livability (quality of life), and sustainability of societies (Mansor, Said, \& Mohammad, 2010; Nasution \& Zahrah, 2012) (Figure 1). Thus, as for the present study area which too confronts the aforesaid ecological issues that convincingly related to inefficient property institution which has been sparsely discoursed (Colding et al., 2013), several doubts are posed like what and how is Sabah's practice with regard to property rights structure view in POS governance and the conundrums associated with it? Due to the tension, property-rights-based approach is commonsensibly employed as the crux in shedding new light (Webster, 2005) of which; we endeavour to (i) examine Sabah's current practice in urban-rural POS governance and, (ii) explore the POS' social dilemmas and negative externalities of Sabah's status quo pertaining to practice.

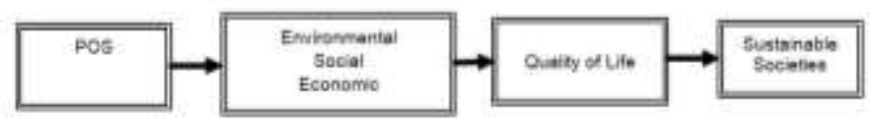

Figure 1: Relationship between the POS and societies' quality of life and sustainability Source: Adapted from Chiesura (2004)

\subsection{Literature Review}

\subsection{Theory and Review of Property-Rights Regimes and Bundle of Property Rights on POS}

Table 1: Four types of property-rights regimes with owners' rights, duties, ownership and access

\begin{tabular}{|c|c|c|c|c|}
\hline Regimes & Ownership & Owner rights & Owner duties & Access \\
\hline Private property & Individual & $\begin{array}{c}\text { Socialy acceptable } \\
\text { and access control }\end{array}$ & $\begin{array}{c}\text { Avoid socially } \\
\text { unacceptable } \\
\text { uses }\end{array}$ & Closed \\
\hline $\begin{array}{c}\text { Common property (public- } \\
\text { closed access) }\end{array}$ & Collective & $\begin{array}{c}\text { Exclusion of non } \\
\text { members }\end{array}$ & $\begin{array}{c}\text { Maintenance- } \\
\text { restrict the rate of } \\
\text { use }\end{array}$ & $\begin{array}{c}\text { Group } \\
\text { members only }\end{array}$ \\
\hline State property & Government & Determine nules & $\begin{array}{c}\text { Maintain social } \\
\text { objective }\end{array}$ & All \\
\hline $\begin{array}{c}\text { Open-access resource } \\
\text { (public-open access) }\end{array}$ & None & None & None & All \\
\hline
\end{tabular}

Source: Adapted and slightly modified from Hanna et al.,(1996)

To comprehend the property rights institution which is not institutionally-vacuum subsisted (Musole, 2009), particularly in resource domain governance, Buck (1998) argues, it is 
relevant to distinguish the constituents within the property structure which comprise property rights regimes and a bundle of property rights. As for property regimes (about the rights of ownership and control allocation), quintessentially, there are four categories of regimes (Buck, 1998) but in reality, those regimes overlap each other instead (Satria, Matsuda, \& Sano, 2006). Hanna et al., (1996) contend those regimes (Table 1) are critical institutions that organise the social-ecological interaction, more incisively, behavioural patterns and actions of stakeholders' are formed in determining the resources' outcome.

Generally, relative property rights are economic claims or ability to the resources (either de jure or de facto authorised (Schlager \& Ostrom, 1992). Within their oeuvre viz. property rights typology, there are five economic rights colligated accordingly with different positions (Table 2) that become essential heuristic for the study area analysis. Anyhow, both property regimes and property rights are cogently interdependent in moulding the POS' outcomes as rights and duties assignation, which is like an agreement or 'contract' (Lee et al., 2013) between parties, determines human-ecological interaction respecting its natures of consumption and betterment whether it leads to the dilemmas and livability issues.

Table 2: Bundle of property rights in resources that associated with different right-holders

\begin{tabular}{|c|c|c|c|c|c|}
\hline Bundle of rights & \multicolumn{3}{|c|}{ Collective-choice rights holders } & \multicolumn{2}{|c|}{$\begin{array}{c}\text { Operational-level rights } \\
\text { holders }\end{array}$} \\
\cline { 2 - 6 } & Owner & Proprietor & Claimant & $\begin{array}{c}\text { Authorised } \\
\text { user }\end{array}$ & $\begin{array}{c}\text { Authorised } \\
\text { entrant }\end{array}$ \\
\hline Access (right to enter) & $x$ & $x$ & $x$ & $x$ & $x$ \\
\hline $\begin{array}{c}\text { Withdrawall Use (right to } \\
\text { obtain) }\end{array}$ & $x$ & $x$ & $x$ & $x$ & \\
\hline $\begin{array}{c}\text { Management (right to } \\
\text { regulate use \& improve) }\end{array}$ & $x$ & $x$ & $x$ & & \\
\hline $\begin{array}{c}\text { Excusion (right to } \\
\text { determine access rights) }\end{array}$ & $x$ & $x$ & & & \\
\hline $\begin{array}{c}\text { Alienation (right to sell or } \\
\text { lease) }\end{array}$ & $\mathrm{x}$ & & & & \\
\hline
\end{tabular}

Source: Adapted from Schlager \& Ostrom (1992)

\subsection{Property-Rights Structure, POS' Social Dilemmas, and Quality of life}

In light of the property rights that affirmed by Satria, Matsuda \& Sano (2006), it indeed determines the type of goods of which, the POS' economic goods is paradigmatically transformed from ideal pure public good into a common pool resource (CPR). Such CPRbased good is vulnerable to social dilemmas (commons dilemmas). Many scholars nem con asserted that, emergence of them are pertinent to the property rights failures i.e., the complex issues of security (Kim, 2004), definition (Coase, 1960), completeness (Baker, 2006; Nicita, Rizzolli, \& Rossi, 2007), attenuation (robustness) (Furubotn \& Pejovich, 1972), and adaptiveness of assignment (Webster \& Lai, 2003; Kim, 2004; Ostrom, 2008), of rights are 
substantial as they define the incentive and (transaction) costs, willingness, ultimately the enforceability and enforcement which simultaneously shapes individuals' behaviour and action (Musole, 2009) whether to behave opportunistically in POS market.

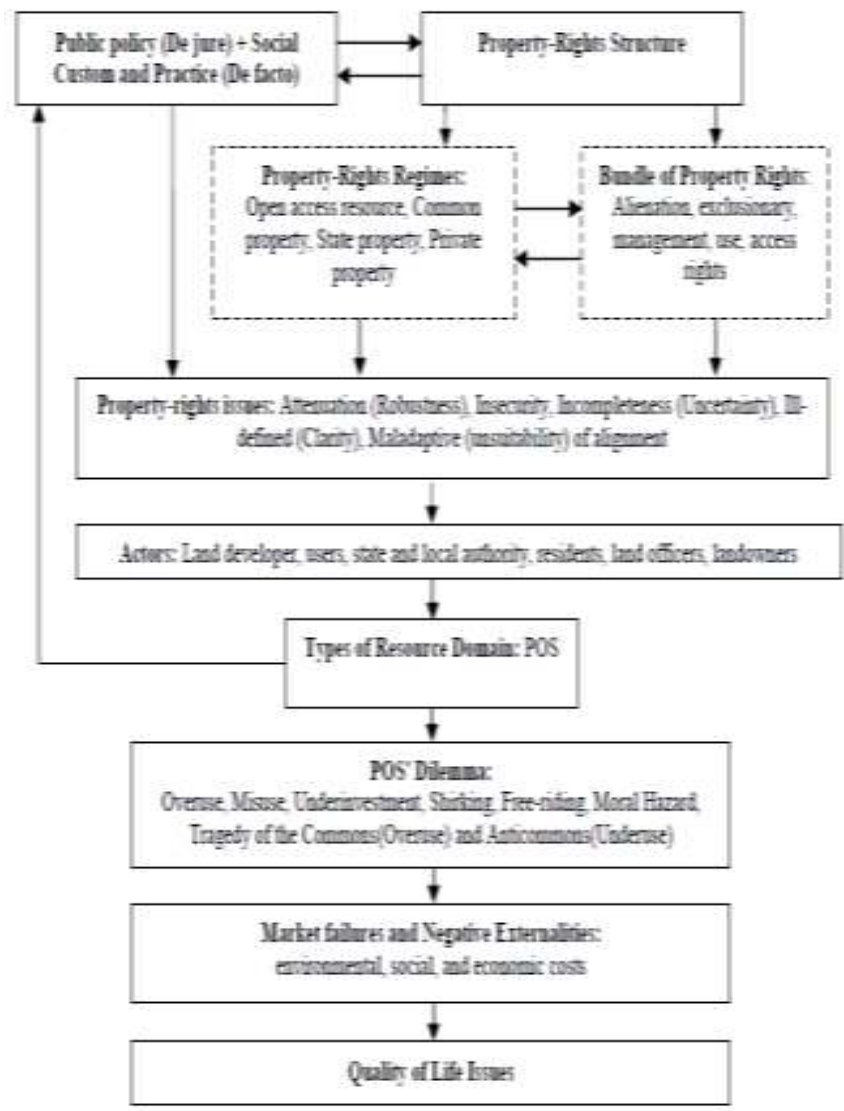

Figure 2: Institutional property-rights structure as the determinant of quality of life Source: Adapted and slightly modified from Gerber et al.,(2009)

In pursuit of clearer views on how POS' quality is affected by institutional rights, various forms of social dilemmas are illustrated as follows; individuals overuse the space for illegal functions, e.g., waste disposal site (Garnett, 2012), low-cost condominium houses, squatting (Kassa, 2008), or vandalism and graffiti and littering (Garnett, 2012): parks and equipment are left desolate and broken (Foster, 2011), which, bring panhandling, (Garnett, 2012), and overcrowded (Webster, 2007) issues. Ergo, all these property-rights-triggered POS' negative externalities drive the degraded POS deemed unsafe and insecure (criminal activity), dirty, 
unattractive, congested and derelict space that consequently pose quality of life issues not only ecological and economic aspect but also social: physical and psychological health concern: heart-attack and social disintegration. Such relationship of institutional POS' dilemma and quality of life is portrayed in Figure 2.

\subsection{Methodology}

\subsection{The Study Area}

Capital city of Kota Kinabalu (KK) that surrounded by about 400 territorial POS (in 2013) within Country land including Native land (rural) and Town land (urban) with an approximate area and population of $351 \mathrm{~km}^{2}$ and 452,058 (year 2010) respectively which, falls within the West Coast Division of Sabah, Malaysia (Figure 3), was selected as the site study. Hitherto, only both headquarters of KK Lands and Surveys Department (LSD) and City Hall (CH) as the key informants (policy-makers) were focused as their verdicts made concerning practice in POS governance are constitutionally enforced in all other districts of the State.

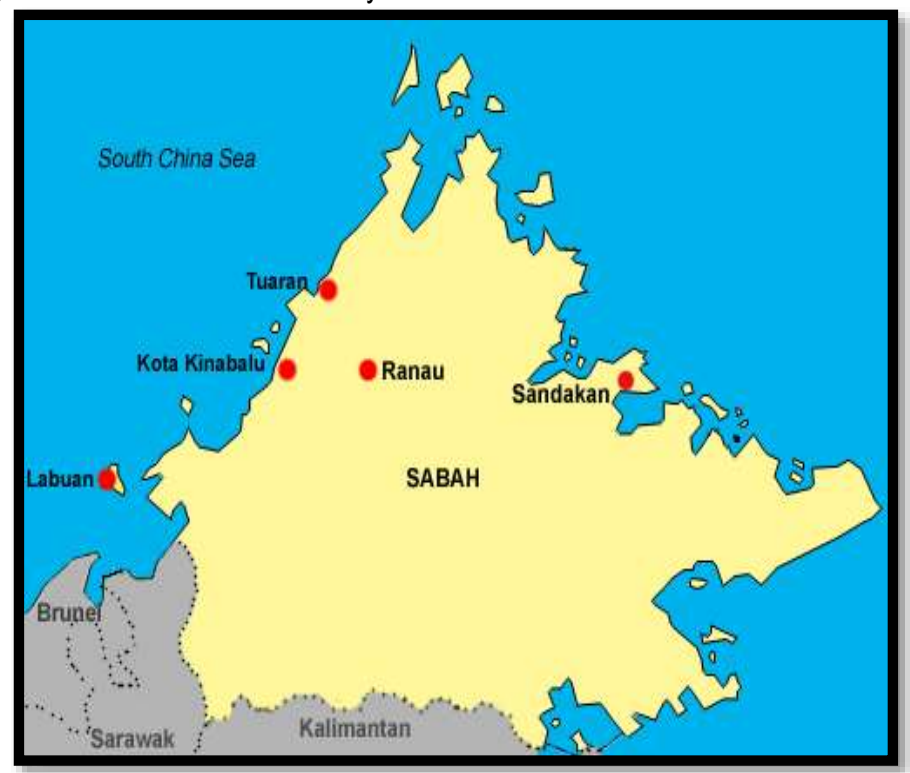

Figure 3: Map showing location of KK, Sabah, Malaysia

\subsection{Data Collection and Data Analysis}

This paper employs case study strategy to exemplify Sabah's practice on POS governance and its POS' dilemmas that appertain to livability issues. As for the first objective, besides the secondary data collection: local government POS reports and presentations, archival 
search: random POS' title deed search, offer letters, legal document reviews, primary data were complementarily gathered via semi-structure interviews (face-to-face technique). As for the second objective, it was hitherto garnered via pilot test on two local government officers and land officers from different organisations, CH and LSD respectively. Semi-structured interviews (via phone calls and emails) were conducted. Furthermore, qualitative content (thematic/ coding) analysis was executed on the interviews data.

\subsection{Results and Discussions}

\subsection{Diverse Property-Rights Structure Natures in POS Governance}

The result of the first objective shows that Sabah's current practice in POS governance is delineated by title deed system, i.e., POS' title deed is only granted on Country Lease (CL) and Town Lease (TL) while the Native Title, (NT) POS would be otherwise. All the respondents acknowledge such long-established practice, by citing the case of Sabindo Nusantara Sdn Bhd \& Anor v Majlis Perbandaran Tawau \& Ors [2011] 8 MLJ 653 that indeed title deed is only granted on the CL space but this provision does not impose on the NT's POS due to some other reasons, e.g., transfer difficulty issue. Since the open space is meant for public use e.g., for recreational purpose (TCPO), then the ownership right of some types of POS are straightaway held as state property (like NT POS) but with attenuated rights (without exclusion and alienation) (Musole, 2009) except for the initial stage of titled POS like $\mathrm{CL} / \mathrm{TL}$ POS whereby the management duty, as well as ownership on CL and TL's POS, are determined by title possession, more precisely, site transferability. If the title and site are yet to be transferred and held by, e.g., developer, then he should bear the initial POS development and management obligations. Veritably, such management duty is aligned by the title's prerequisite stating that such duties shall be enforced up to the local authority's satisfaction only then the compulsory title transfer to government is permitted. This (tite transfer and site handing over) is too substantiated by Sabindo's case, based on the Modified Torrens System, albeit the individual retains the POS' title, it does not entail ownership; instead, it is merely a trusteeship which is duty-bound to execute the transfer to a local authority (beneficiary) after fulfilling the management responsibility. Note that, even the title transfer has not been undertaken, so long as the management of developer has accomplished the local authority's requirement, the site transfer is allowable, and if it were attempted, then it entails that, he ('bare' trustee) has officially relinquished the management right to the authority. Succinctly, consistent with Musole's (2009) idea, indeed Sabah's property-rights in POS governance cannot be institutionally vacuumed, in lieu, it is a practicebased rights, i.e., the composite practice causes the property-rights structure diverseness in urban-rural POS governance (Table 3). 
Table 3: A de jure overview of diverse property rights and regimes positions of Sabah's POS governance.

\begin{tabular}{|c|c|c|c|c|}
\hline $\begin{array}{l}\text { Property-Rights } \\
\text { structure }\end{array}$ & $\begin{array}{c}\text { CL \& TL'S POS } \\
\text { (Un-transforred titie) } \\
\text { (Un-transferred site) }\end{array}$ & $\begin{array}{l}\text { CL \& TL's POS } \\
\text { (Un-transferred titie } \\
\text { due to un-issuance } \\
\text { of lille) } \\
\text { (Transferred site) }\end{array}$ & $\begin{array}{c}\text { CL \& TL'S } \\
\text { POS } \\
\text { (Transferred } \\
\text { vitle) } \\
\text { (Transferred } \\
\text { site) }\end{array}$ & $\begin{array}{c}\text { NT's POS } \\
\text { (Without title) } \\
\text { (Neediess site } \\
\text { transfer) }\end{array}$ \\
\hline Landownership & $\begin{array}{l}\text { Pivate/ Commen } \\
\text { propenty }\end{array}$ & stale property & State property & State property \\
\hline Management & $\begin{array}{c}\text { Private / Common } \\
\text { Property }\end{array}$ & Govemment & Government & Government \\
\hline $\begin{array}{l}\text { Positions: } \\
\text { Bundie of rights: }\end{array}$ & $\begin{array}{l}\text { Claimant } \\
\text { (Developed, } \\
\text { Landowner(a)\} }\end{array}$ & $\begin{array}{c}\text { Claimant } \\
\text { (Local government) }\end{array}$ & $\begin{array}{c}\text { Claimant } \\
\text { (Local } \\
\text { govemment) }\end{array}$ & $\begin{array}{l}\text { Claimant } \\
\text { (Local } \\
\text { govemment) }\end{array}$ \\
\hline Access & $x$ & $x$ & $x$ & $x$ \\
\hline Withdrawal & $x$ & $x$ & $x$ & $x$ \\
\hline Management & $x$ & $x$ & $x$ & $x$ \\
\hline $\begin{array}{l}\text { Public access and } \\
\text { withdrawal rights }\end{array}$ & Yes & Yos & Yes & Yos \\
\hline
\end{tabular}

\subsection{Institutional Rights Structure Arises Urban-Rural POS' Dilemma and Livability Issues}

While, as for the second objective's pre-test result, tersely, Sabah's practice-based diverse property-rights that embrace contestations like rights mal-alignment of state property, rights attenuation, and incompleteness of rights, obligations and sanctions have prima facie triggered the urban-rural POS dilemma (due to less incentive and unenforceable issues). Such position is supported by the CH's respondents that, roughly 40 percent of the total 400 rivalry state-owned POS are not in favourable condition which, involve vandalised equipment and broken infrastructure, e.g., damaged fence, overgrown grass, spaces illegally become a house-extension, mosquitoes breeding ground, dumping ground, car-park, vegetation, and overcrowded issues especially in urban spaces as well as, illegal exclusion on spaces added by the LSD respondent. Under the state-managed POS, the management efficiency is primarily relying on the budget allocation, but sadly, a fiscal crisis is unavoidably confronted which has induced some under-provisioned POS. This indicates positive transaction cost (fiscal issue) (Webster \& Lai, 2003) indeed becomes an impediment to local authority to enforce the management rights on the urban-rural POS (shirking issue: inefficient management and monitoring system). This is certainly a form of regulatory slippage (Foster, 2011) in which, a transformation from legal state regime to de facto open access resource of POS is elusively taken place that can exacerbate the condition of spaces whereby, the users' opportunism triggered off due to government unenforced rights. This is even concerted by the CH's respondents that, urban POS, e.g., promenade or city park (minority) conditions are more superior than the community park in a residential area because guards are hired to do surveillance task: to monitor users' behaviour on the urban space utilisation which is a part of a management right, while, less or no surveillance and maintenance are afforded for the residential commons (residents involved in overuse and moral hazard). Moreover, within the 
Sabindo's case, the POS had been used by the government for commercial shop lots and, even some spaces in KK also faced the similar fate added by the respondent. This means some spaces may opportunistically be overused for the private purpose by the government especially; the ownership is retained by them. Besides, under-specified rights and obligations within the informal 'contract', users, owners or government, they may 'tempt' to misbehave on the spaces (See, Williamson, 2002 on ex-post opportunism).

Next, the privately-managed who do not possess the full-ownership (attenuated) on the POS, and are adhered to mandatorily transfer it to local authority after satisfying the obligations, may be incentivised to shirk, and overuse (Furubotn \& Pejovich, 1972) because they think the 'bare' rights does not confer any incentive (not even single penny from users; instead, all revenues go to the government), which at last to be handed over, so, what is the purpose for overhauling it? This is also agreed by the LSD' respondents that, this practice is cumbersome and unrealistic as owners may find it difficult that, they do not only have to invest but also transfer them, in which, all the cream of the crop will fully be reaped by the government. So, they may not willingly or reluctant to enforce the management rights, and most importantly, it is not their property, like CH's respondents argued that, some developers delayed the maintenance until the eleventh hour before the transfer (which caused the spaces were interim left unmanaged). Additionally, since users are not the owners, they are prone to overuse or act moral hazard like the antecedent state-managed POS situation as "one household only shovels the snow outside's one's door. No one cares about the frost above the roofs of others' home" (Chinese byword). Noticeably, regardless of state or privately-managed POS, due to the property-rights failures, all has practically become an open-access resource in which, the tragedy of urban-rural POS is posed. All these institutionally-triggered opportunisms and self-interestedness on the POS that confirmed Hanna et al., (1996) and Schlager \& Ostrom (1992) purviews that property institution indeed matters in social-ecological interaction particularly, about POS' conditions, have plausibly posed quality of life issues. Salient connection between Sabah's institutions, POS' dilemmas and life quality, can, therefore, be analogous to the conceptual framework of Figure 4 above.

\subsection{Conclusion}

In a nutshell, this study has established the property-rights structure diverseness of Sabah's present practice in urban-rural POS governance. A relationship between such institution of POS governance and quality of life is likewise unveiled, i.e., various institutional triggered social dilemma are posed. These findings have thereof bridged the lacuna of property-rights in new commons, POS, and livability issue. Several mechanisms are purported as the dilemma's solutions such as an approach by the Nobel Laureate, Ostrom (1990) on commonproperty-based eight principles of self-governing and organising the resource. The fundamental essence is a particular group is assigned rights to control and manage the POS (collective action), e.g., Home Owner Association, (HOA), but it may also require Leviathan state intervention (as a monitor) via contractual arrangement (Williamson, 2002; Chen \& 
Webster, 2006). The entire idea is to introduce an entrepreneurial club good concept instead of CPR good.

\section{References}

Baker, S. (2006). Incomplete Contracts in a Complete Contract World, paper presented at the Law and Economics of Intellectual Property Workshop of the University of Michigan Law School.

Buck, S.J. (1998). The global commons: an introduction (Washington, DC: Island Press). p 3.

Chen S.C.Y., \& Webster, C. (2006). Privatising the governance and management of existing urban neighbourhoods. Property Management, 24(2), 98-115.

Chiesura A. (2004). The role of urban parks for the sustainable city. Landscape and Urban Planning, 68(1), 12938.

Coase, R. H. (1960). The problem of social cost. Journal of Law and Economics, 3, 1-44.

Colding J., Barthel S., Bendt P., Snep R., van der Knaap W., Ernstson H. (2013). Urban green commons: Insights on urban common property systems. Global Environmental Change.

Foster, S., (2011). Collective Action and the Urban Commons. Notre Dame Law Review, 87.

Furubotn, E. G., \& Pejovich, S. (1972). Property rights and economic theory: A survey of recent literature. Journal of Economic Literature, 10(4), 1137-1162.

Garnett, N.S. (2012). Managing the Urban Commons. Notre Dame Legal Studies, No. 11-44.

Gerber, J.D., Knoepfel P., Nahrath, S., \& Varone, F. (2009). Institutional Resource Regimes: Towards sustainability through the combination of property-rights theory and policy analysis. Ecological Economics, 68(3),798-809.

Hanna, S.S., Folke, C., \& Maler, K.G. (1996). Rights to Nature: Ecological, Economic, Cultural and Political Principles of Institutions for the Environment. Island Press, Washington, DC.

Hardin, G. (1968). The tragedy of the commons. Science, 162, 1243-48.

Hess, C. (2008). Mapping the New Commons, paper presented at the 12th Biennial Conference of the International Association for the Study of the Commons, University of Gloucestershire, Cheltenham, 14-18 July.

Kassa, D.G. (2008). A Tragedy of the "Urban Commons"? A case study of 2 Public Places in Addis Ababa. pp: 113.

Kim, A. (2004). A market without the "right" property rights. Economics of Transition, 12(2), 275-305.

Lee, S.S., Webster, C.J., Melián, G., Calzada G., \& Carr R. (2013). A Property Rights Analysis of Urban Planning in Spain and UK. European Planning Studies. p 1-16.

Mansor, M., Said I., Mohamad I. (2010). Experiential Contacts with Green Infrastructure's Diversity and Well-being of Urban Community. ajE-Bs, Asian Journal Of Environment-Behaviour Studies, 33-48. 
Ling, G.L.T., et.al. / Asian Journal of Environment-Behaviour Studies (ajE-Bs), 3(10) Sep / Oct 2018 (p68-77)

Musole, M. (2009). Property rights, transaction costs and institutional change: Conceptual framework and literature review. Progress in Planning, 71(2), 43-85.

Nasution, A.D., \& Zahrah, W. (2012). Public Open Space 's Contribution to Quality of Life : Does privatisation matters? ajE-Bs, Asian Journal Of Environment-Behaviour Studies, Volume 3, Number 9.

Nicita, A., Rizzolli, M., \& Rossi, AM. (2007). Towards a Theory of Incomplete Property Rights. American Law \& Economics Association Annual Meetings.

Ostrom, E. (1990). Governing the Commons: The Evolution of Institutions for Collective Action. Cambridge University Press, Cambridge.

Ostrom, E. (2008). Institutions and the environment. Economic Affairs, 28(3), 24-31.

Satria, A., Matsuda, Y., \& Sano M. (2006). Contractual solution to the tragedy of property right in coastal fisheries. Marine Policy, 30(3), 226-36.

Schlager, E., \& Ostrom, E. (1992). Property-Rights Regimes and Natural Resources: A Conceptual Analysis Property-Rights Regimes and Natural Resources, 68(3), 249-62.

Webster, C. (2007). Property rights, Public Space and Urban Design. 78, 81-102.

Webster, C.J., \& Lai, W.C. (2003). Property rights, planning and markets: Managing spontaneous cities. (Cheltenham, UK; Northampton, MA: Edward Elgar).

Webster, C. (2005). Editorial: Diversifying the institutions of local planning. Economic Affairs, 25(4), 4-10.

Williamson, O.E. (2002). The Theory of the Firm as Governance Structure: From Choice to Contract, Journal of Economic Perspectives, (16:Summer), pp. 171-195. 